\title{
Pengembangan Bahan Ajar Kimia Materi Hidrolisis Garam dengan Pendekatan Scientific Inquiry Berbasis Problem Based Learning
}

\author{
Wiji Chusnah $^{1}$, Suhadi Ibnu ${ }^{1}$, Sutrisno ${ }^{1}$ \\ ${ }^{1}$ Pendidikan Kimia-Universitas Negeri Malang
}

\begin{tabular}{l}
\hline INFO ARTIKEL \\
\hline Riwayat Artikel: \\
Diterima: 10-03-2020 \\
Disetujui: 19-07-2020 \\
\hline Kata kunci: \\
teaching materials development; \\
salt hydrolysis; \\
scientific inquiry approach; \\
problem based learning; \\
pengembangan bahan ajar; \\
hidrolisis garam; \\
pendekatan scientific inquiry; \\
problem based learning
\end{tabular}

Alamat Korespondensi:

Wiji Chusnah

Pendidikan Kimia

Universitas Negeri Malang

Jalan Semarang 5 Malang

E-mail: chusnahwj@ gmail.com

\section{ABSTRAK}

\begin{abstract}
This development research aims to produce chemical teaching material products with a problem-based scientific inquiry approach based on the 4-D (four-D) model of Thiagarajan, Semmel and Semmel with the stages of define, design, develop, disseminate through a cross-sectional survey. The method used in the survey at the define stage is through literature review of chemistry textbooks. The results of the development of chemistry teaching materials salt hydrolysis material are empirically validated by content experts and chemistry learning material experts are considered valid with an average score of 3.67 and suitable for use as teaching materials.
\end{abstract}

\begin{abstract}
Abstrak: Penelitian pengembangan ini bertujuan untuk menghasilkan produk bahan ajar kimia dengan pendekatan scientific inquiry berbasis problem based learning model 4-D (four-D) Thiagarajan, Semmel dan Semmel dengan tahapan define, design, develop, disseminate melalui survey cross secsional. Metode yang digunakan dalam survei pada tahap define melalui kajian literatur buku teks pelajaran kimia. Hasil pengembangan bahan ajar kimia materi hidrolisis garam tervalidasi secara empirik oleh ahli isi dan ahli materi pembelajaran kimia dinilai valid dengan skor rata-rata 3,67 dan layak digunakan sebagai bahan ajar.
\end{abstract}

Penelitian ini bertujuan untuk mengembangkan bahan ajar kimia melalui tahapan analisis konsep. Kegiatan analisis konsep bertujuan menganalisis perbedaan representasi kimia dalam buku teks pelajaran kimia dan membandingkan dengan apa yang sebenarnya terjadi dalam pembelajaran. Representasi kimia dalam pembelajaran kimia, meliputi representasi makroskopis, mikroskopis, dan simbolik. Hasil analisis juga menunjukkan bahwa perubahan kurikulum pembelajaran kimia membutuhkan buku teks pelajaran kimia untuk menerapkan aspek materi yang mencakup pengetahuan fakta dan konsep, prosedural dan metakognitif, kebenaran dan keakuratan materi, kemutakhiran data dan konsep, serta dapat mendukung pencapaian tujuan pendidikan nasional sesuai dengan kurikulum yang berlaku (Kemendikbud, 2016a).

Berdasarkan hasil kajian kepustakaan dalam buku teks pelajaran kimia di sekolah dapat diamati bahwa sebagian besar buku sampel sebagai sumber belajar belum memenuhi karakteristik materi pembelajaran sesuai dengan hakekat sains. Hal ini menunjukkan bahwa keterlibatan siswa dalam berbagai keterampilan proses sains, keterampilan berpikir kritis, pemahaman konsep, pemahaman algoritmik dan numerik, literasi sains perlu ditingkatkan (Johnson et al., 2011). Karakteristik berpikir menurut Ennis (2011) dibedakan berdasarkan kemampuan dan pemahaman yang telah dimiliki untuk menerapkan natural of critical thinking. Paradigma pembelajaran kimia abad 21 menekankan keterampilan berpikir kritis, keterampilan berpikir tingkat tinggi, literasi sains, komunikasi dan kolaborasi. Pendekatan scientific menerapkan kegiatan literasi sains yang menekankan pada pembelajaran kimia dalam kehidupan sehari-hari diperlukan untuk pemahaman konsep dan mengembangkan keterampilan berpikir kritis. Literasi sains siswa menekankan bahwa memahami issue lingkungan dikaitkan dengan konsep dasar kimia, konten, konteks materi kimia sebagai bahan pelajaran kimia agar mudah dipahami siswa (Shwartz et al., 2006).

Pengembangan issue lingkungan dalam pembelajaran kimia memerlukan integrasi konten dan skills (keterampilan) relevan dengan pengetahuan ilmiah yang dibutuhkan oleh siswa (Buxner, 2015). Pembelajaran dengan pendekatan scientific inquiry berbasis problem based learning dalam penelitian ini dikembangkan untuk pemahaman konsep dan meningkatkan keterampilan berpikir kritis (critical thinking skills). Pemahaman konsep yang diperoleh siswa berhubungan erat dengan informasi, interpretasi bacaan dan struktur materi buku teks yang diterapkan dalam interaksi proses belajar di kelas (Osman et al., 2013). Skema kegiatan belajar dengan pendekatan scientific inquiry berbasis problem based learning dalam penelitian ini dapat dilihat pada gambar 1. 


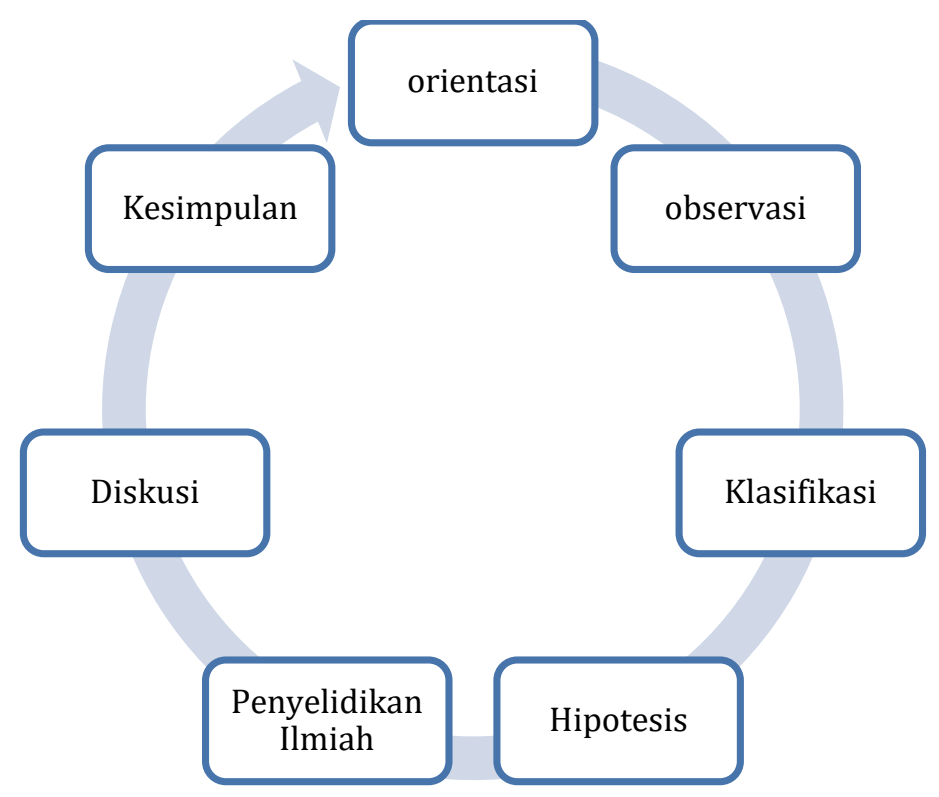

\section{Gambar 1. Kegiatan Belajar dengan Pendekatan Scientific Inquiry Berbasis Problem Based Learning}

Uraian kegiatan belajar dalam buku kimia menunjukkan keterlibatan siswa dalam keterampilan proses sains dengan pendekatan scientific inquiry konsisten dengan tingkat contoh dan investigasi. Kegiatan belajar dalam kelas yang menggunakan buku teks pelajaran kimia mulai menerapkan penggunaan logika dan berpikir kritis dengan melibatkan siswa dalam proyek, aktif dalam proses penemuan dan konstruk makna dengan arahan guru untuk memahami makna ide ilmiah sehingga didapatkan target kurikulum sesuai dengan standar isi kurikulum yang berlaku (Borda et al., 2017). Pendekatan scientific inquiry berbasis problem based learning melalui pengamatan fenomena makroskopis membutuhkan improvisasi dari pendekatan saintifik agar mudah dipahami siswa dalam level mikroskopis berkaitan dengan level simbolik. Siswa harus mampu berpikir dengan cepat dari satu level representasi mencapai level representasi lainnya berdasarkan konsep dasar yang telah dipahami siswa. Diskusi tentang materi yang dipelajari dalam buku teks pelajaran kimia berkaitan dengan data pengamatan memerlukan model pembelajaran untuk melibatkan siswa.

Sumber belajar dalam bentuk buku teks pelajaran kimia didukung materi yang benar secara empirik dan teoritik diharapkan dapat mendorong timbulnya motivasi kemandirian, inovasi untuk mengembangkan diri bagi siswa sekolah menengah atas (Pendidikan et al., 2016). Keberhasilan implementasi kurikulum untuk siswa dan guru tergantung pada kemampuan guru mengembangkan bahan ajar (Wang et al., 2014). Penelitian tentang bahan ajar menunjukkan bahwa pengembangan bahan ajar seringkali hanya digunakan untuk menunjukkan hasil pengembangan dan bukan untuk memenuhi tuntutan pemenuhan kebutuhan kompetensi siswa. Berdasarkan hal ini sistematika urutan materi dengan pendekatan scientific inquiry yang disajikan dalam buku teks pelajaran kimia secara hierarkis dan berjenjang terkait dengan skema pengorganisasian pembelajaran diharapkan dapat memenuhi kebutuhan kompetensi siswa (Gültepe, 2016).

\section{METODE}

Penelitian pengembangan ini menggunakan model 4-D (four- D) Thiagarajan, Semmel dan Semmel (1974) dengan tahapan define, design, develop, disseminate melalui survey cross secsional analisis konten data hasil penelitian terdahulu. Interpretasi data penelitian yang diperoleh dianalisis dengan analisis deskriptif kualitatif dan kuantitatif. Metode yang digunakan dalam survey pada tahap define melalui kajian literatur buku teks pelajaran kimia di Indonesia kurikulum 2013 dan kurikulum 2013 edisi revisi. Hasil survey digunakan untuk mendapatkan deskripsi pembelajaran buku teks yang disusun berdasarkan analisis kurikulum secara kualitatif tahap design. Tahap develop menerapkan interpretasi data hasil survey terhadap buku teks dibandingkan dengan buku teks pelajaran kimia yang disusun sebagai produk hasil pengembangan. Pengembangan buku teks berdasarkan penelitian beberapa ahli untuk mendapatkan data perbedaan representasi kimia. Upaya pengembangan bahan ajar kimia materi hidrolisis garam dilakukan dengan pendekatan scientific inquiry berbasis problem based learning. Validasi dilakukan oleh ahli isi, ahli materi untuk mendapatkan kualifikasi kelayakan, validitas dan keefektifan produk hasil pengembangan. Tahap disseminate melalui uji coba perorangan, uji kelompok terbatas untuk mendapatkan data keefektifan bahan ajar oleh pengguna melalui uji keterbacaan. 


\section{HASIL}

Dari hasil kajian diperoleh data bahwa buku teks pelajaran kimia yang digunakan di sekolah menunjukkan adanya perbedaan. Penerapan dimensi pengetahuan dalam buku teks yang terdiri dari pengetahuan faktual, konseptual, prosedural dan metakognitif dalam materi belajar untuk siswa berdasarkan silabus dan kurikulum yang berlaku. Pemahaman konsep melalui pengetahuan, pemahaman, analisa, aplikasi, sintesa, evaluasi dan kreatif. Karakteristik Problem Based Learning menunjukkan bahwa siswa mempelajari konten, strategi, dan keterampilan belajar mandiri.

Dimensi keterampilan dalam ranah konkret, meliputi kemampuan menggunakan, menguraikan, merangkai, merancang percobaan, menyajikan, dan menciptakan karya (Kemendikbud, 2016b). Untuk menghasilkan proses pembelajaran dengan mengonfirmasi hasil belajar yang diperoleh dan dapat diterapkan dalam kehidupan sehari-hari tidak dapat diuji hanya dengan benda atau contoh dalam bentuk gambar atau diagram saja. Berpikir kritis untuk analisis dan memecahkan masalah kompleks reaksi kimia dalam kehidupan sehari-hari, menemukan evaluasi dan menggunakan penelitian, bekerja kelompok dalam regu dan kelompok kecil, berkomunikasi, menulis, membaca, menggunakan pengetahuan dan keterampilan belajar. Konsep kimia meliputi perhitungan, komposisi, ikatan, struktur molekul, fenomena kimia berkaitan dengan gagasan teoritis dan hukum dasar kimia yang diterapkan dalam beberapa buku teks sebagai bahan rujukan materi asam dan basa, larutan buffer, hidrolisis garam disajikan pada tabel 1.

Tabel 1. Konsep dan Aktivitas Belajar Siswa

\begin{tabular}{lll}
\hline Aktivitas Belajar & Konsep Relevan & Fenomena \\
\hline Larutan Asam dan Basa & Substansi asam basa, $\mathrm{pH}$, & Hujan asam, pencemaran \\
& indikator & udara, air sadah \\
Larutan Buffer & Asam basa konjugasi, pH, buffer & pH darah, asam \\
& asam, buffer basa & lambung, \\
Sifat keasaman garam & Sifat larutan garam, hidrolisis & $\begin{array}{l}\text { Penggunaan pupuk, } \\
\text { garam, pH larutan garan }\end{array}$ \\
& sabun, detergen
\end{tabular}

Sumber : Syllabus (IGCSE Cambridge, 2015)

Penjelasan materi pelajaran kimia dalam kelas dibedakan dalam level makroskopis, mikroskopis dan representasi simbolik. Representasi makroskopis, mikroskopis dan simbolik dalam buku teks pelajaran tradisional sebagian tidak mencerminkan perhatian terhadap isi dan konteks materi berhubungan dengan perkembangan ilmu pengetahuan dan teknologi, penerapan pendekatan sesuai dengan keadaan siswa untuk meningkatkan keterampilan berpikir kritis (Şener \& Tü, 2015). Representasi kimia membutuhkan konteks yang kontekstual dan benar-benar terjadi dalam keadaan sebenarnya yang dapat diamati secara langsung. Untuk mengatasi kekurangan ini maka penjelasan konteks dengan hukum-hukum ilmiah dan prinsip kimia. Kegiatan belajar mendorong akses realitas objek dan fenomena berdasarkan pengamatan. Pemahaman konsep kimia misalnya asam, basa, garam dan elemen (unsur) pada tingkat makro atau tingkat mikro secara umum dalam setiap buku menjadi bagian minimal dari substansi ditingkat mikro menunjukkan komposisi kuantitatif dalam menentukan molekul, ion atau atom pada tingkat mikro (Rahayu \& Kita, 2010).

Pemahaman konseptual dan algoritmik materi asam basa menggunakan pendekatan mikroskopis materi asam basa menunjukkan hasil belajar yang lebih baik. Keuntungan penggunaan pembelajaran dengan model penggambaran mikroskopis dalam pembelajaran kimia dapat meningkatkan kemampuan pemahaman mengenai gejala apa yang terjadi pada tingkat mikroskopis memudahkan siswa menerima konsep yang sulit, membantu siswa memvisualisasikan apa yang terjadi pada tingkat mikroskopis (Rahayu et al., 2011). Hasil penelitian beberapa buku teks pelajaran kimia yang digunakan siswa pada tingkat Sekolah Menengah Atas di antaranya dapat dijelaskan sebagai berikut.

\section{Tahap Pendefinisian (Define)}

Pada tahap ini diperoleh data masalah dasar perlunya pengembangan tata urutan materi buku teks pelajaran kimia, karakteristik peserta didik, implementasi kurikulum dan proses kegiatan belajar mengajar di sekolah berdasarkan konten materi sesuai struktur kurikulum yang telah ditentukan. Pengembangan bahan ajar kimia sesuai perkembangan ilmu pengetahuan dan teknologi dengan konten materi yang dikembangkan dalam buku teks pelajaran kimia sering diidentikkan melalui pengembangan pengetahuan kognitif rencana pelaksanaan pembelajaran sesuai kurikulum (Koçakoğlu et al., 2010). Tata urutan materi terkait dengan isi kurikulum telah menjadi orientasi serta strategi kognitif yang bisa dicapai dalam mata pelajaran kimia, meliputi konsep konkret dalam tata urutan materi, level simbolik dalam pembahasan rumus kimia, tatanan senyawa, persamaan reaksi, hukum dasar ilmu kimia, stoikiometri, massa atom relatif, mol (Knaus et al., 2011). Literasi sains diperlukan untuk pemahaman konsep dan mengembangkan keterampilan berpikir kritis siswa terhadap issue lingkungan berkaitan pengembangan konsep dasar kimia, konten, konteks bahan pelajaran kimia agar mudah dipahami siswa (Shwartz et al., 2006). 


\section{Tahap Perancangan (Design)}

Perancangan (design) bahan ajar kimia materi hidrolisis garam dalam penelitian ini berdasarkan representasi kimia buku teks pelajaran kimia. Hasil penelitian representasi kimia pada level makroskopis dengan pengamatan perubahan warna kertas lakmus dan simbolik sebagian besar digunakan dalam buku teks pelajaran berupa persamaan reaksi kimia. Penelitian Rahayu (2009) menjelaskan bahwa respons siswa dalam level makroskopis lebih tinggi daripada level submikroskopis. Representasi makroskopis diperoleh melalui pengamatan terhadap suatu fenomena yang dapat dilihat dan dipersepsi oleh pancaindra atau dapat berupa pengalaman sehari-hari. Representasi submikroskopis yaitu representasi kimia yang menjelaskan tentang struktur dan proses pada level partikel (atom/molekul) terhadap fenomena makroskopis yang diamati. Representasi simbolik yaitu representasi kimia secara kualitatif dan kuantitatif, meliputi rumus kimia, diagram, persamaan reaksi, stoikiometri, dan perhitungan matematik.

\section{Tahap Pengembangan (Develop)}

Berdasarkan data kajian terhadap buku teks pelajaran kimia menunjukkan bahwa belajar bermakna yang menghubungkan informasi yang diterima dalam bentuk konsep memperpanjang daya tahan ingatan (long term memory working). Contohnya konsep asam basa Arrhenius, Bronstead- Lowry dan Lewis dalam buku siswa meliputi bahasa simbolik, konsistensi logika, pemahaman inferensi logika, hubungan sebab akibat, kerangka logika, pemodelan untuk membangun realitas konsep zat murni dalam tingkat makro atau minimal bagian dari substansi (molekul) di tingkat mikro. Pengembangan issue lingkungan dengan integrasi konten dan skills (keterampilan) relevan dengan pengetahuan ilmiah (Schwarz et al., 2009). Tata urutan materi dalam kegiatan belajar dapat dilihat pada tabel 2.

\section{Tabel 2. Karakteristik Kegiatan Belajar Problem Based Learning}

\begin{tabular}{|c|c|}
\hline Karakteristik Problem Based Learning & Kegiatan \\
\hline Siswa mempelajari konten, strategi dan keterampilan belajar mandiri. & Orientasi \\
\hline $\begin{array}{l}\text { Berpikir kritis untuk analisis dan pemecahan masalah kompleks kehidupan } \\
\text { nyata, menemukan evaluasi dan menggunakan penelitian, bekerja kelompok } \\
\text { dalam team dan kelompok kecil, berkomunikasi, menulis, membaca, } \\
\text { menggunakan pengetahuan dan keterampilan belajar }\end{array}$ & $\begin{array}{l}\text { Identifikasi kebutuhan belajar, individu harus } \\
\text { menganalisis masalah, mencoba menemukan penalaran } \\
\text { masalah dan mengumpulkan bahan, mengajak siswa } \\
\text { eksplorasi }\end{array}$ \\
\hline Formula dan evaluasi pertanyaan & Observasi \\
\hline $\begin{array}{l}\text { Desain dan rencana kegiatan untuk mengumpulkan informasi, kualitas dari } \\
\text { kumpulan informasi, menulis informasi, presentasi pertanyaan. }\end{array}$ & $\begin{array}{l}\text { Mencari informasi, merencanakan kegiatan, refleksi } \\
\text { pengalaman dan mengajak inquiry. }\end{array}$ \\
\hline Problem & Klasifikasi \\
\hline $\begin{array}{l}\text { Siswa menganalisis dan mempelajari semua informasi yang dipilih tentang } \\
\text { masalah, data untuk memulai proses pemecahan masalah, data hasil penelitian }\end{array}$ & $\begin{array}{l}\text { Mengumpulkan informasi objektif respons pertanyaan, } \\
\text { mengorganisasikan masalah atau pertanyaan relevan. }\end{array}$ \\
\hline Argumen dan eksplanasi & Hipotesis \\
\hline $\begin{array}{l}\text { Kerja kelompok untuk memahami masalah, menyimpulkan hipotesis umum, } \\
\text { identifikasi pengetahuan yang menjadi isu pembelajaran }\end{array}$ & $\begin{array}{l}\text { Strategi memecahkan masalah untuk menjawab } \\
\text { pertanyaan, menggunakan kata kunci informasi. }\end{array}$ \\
\hline Eksplorasi data pengamatan & Penyelidikan ilmiah \\
\hline $\begin{array}{l}\text { Evaluasi hipotesis yang telah dipelajari untuk mengonstruksi pengetahuan yang } \\
\text { telah dipelajari. }\end{array}$ & $\begin{array}{l}\text { Diskusi cara menjawab pertanyaan, analisa data, } \\
\text { pemecahan masalah relevan, praktik investigasi }\end{array}$ \\
\hline Fasilitator dan kolaborasi belajar & Diskusi \\
\hline Diskusi masalah sebelum dimulai penelitian isu pembelajaran relevan dengan & Diskusi dan presentasi \\
\hline konsep, masalah. & $\begin{array}{l}\text { Proses konstruksi pengetahuan dilanjutkan } \\
\text { pembelajaran dan proses pemecahan masalah }\end{array}$ \\
\hline Refleksi & Kesimpulan \\
\hline $\begin{array}{l}\text { Hubungan antara pemecahan masalah dengan komponen berpikir kritis. } \\
\text { Fakta, ide diidentifikasi sesuai dengan isu pembelajaran dan rencana kegiatan }\end{array}$ & $\begin{array}{l}\text { Pemahaman konsep dilanjutkan kegiatan pemecahan } \\
\text { masalah, bahan ajar untuk siswa dari contoh yang } \\
\text { dijelaskan dalam kelas }\end{array}$ \\
\hline
\end{tabular}

Pemahaman skala penentuan $\mathrm{pH}$, kekuatan asam basa, derajat ionisasi, tetapan kesetimbangan asam $\left(\mathrm{K}_{\mathrm{a}}\right)$, tetapan kesetimbangan air $\left(\mathrm{K}_{\mathrm{w}}\right)$, tetapan kesetimbangan basa $\left(\mathrm{K}_{\mathrm{b}}\right)$ dalam buku teks untuk strategi penyelesaian pemahaman konsep dasar kimia (Burgess et al., 2018). Konsep dasar kimia mencakup teori asam basa, kesetimbangan pengionan larutan garam, reaksi hidrolisis garam merupakan konsep yang dipelajari siswa berdasarkan representasi kimia makroskopis, mikroskopis dan simbolik dalam bentuk larutan (solution) asam, basa dan garam (Naah \& Sanger, 2013).

Pembelajaran kimia larutan level molekuler berdasarkan hasil kajian kepustakaan mempunyai tingkat generalisasi dan keabstrakan tinggi. Aspek karakteristik dari molekul, kebasaan, keasaman, struktur solvasi, hidrasi dan hidrolisis dalam proses pembelajaran harus dapat menerapkan penjelasan tingkat makroskopis dengan gejala-gejala yang diamati dan sifat atom atau molekul tingkat mikroskopis didemonstrasikan dengan objek empirik, konkret dengan simbol atau model (Saukkoriipi \& Laasonen, 2010). Pemahaman konsep hidrolisis garam dalam larutan berdasarkan data hasil penelitian di atas dapat dijelaskan bahwa konsep kimia yang dipelajari pada tingkat sekolah menengah atas sebagian besar bersifat abstrak, hierarki, mikroskopis, dan prosedural. Secara ringkas dapat dijelaskan pada gambar 2 . 


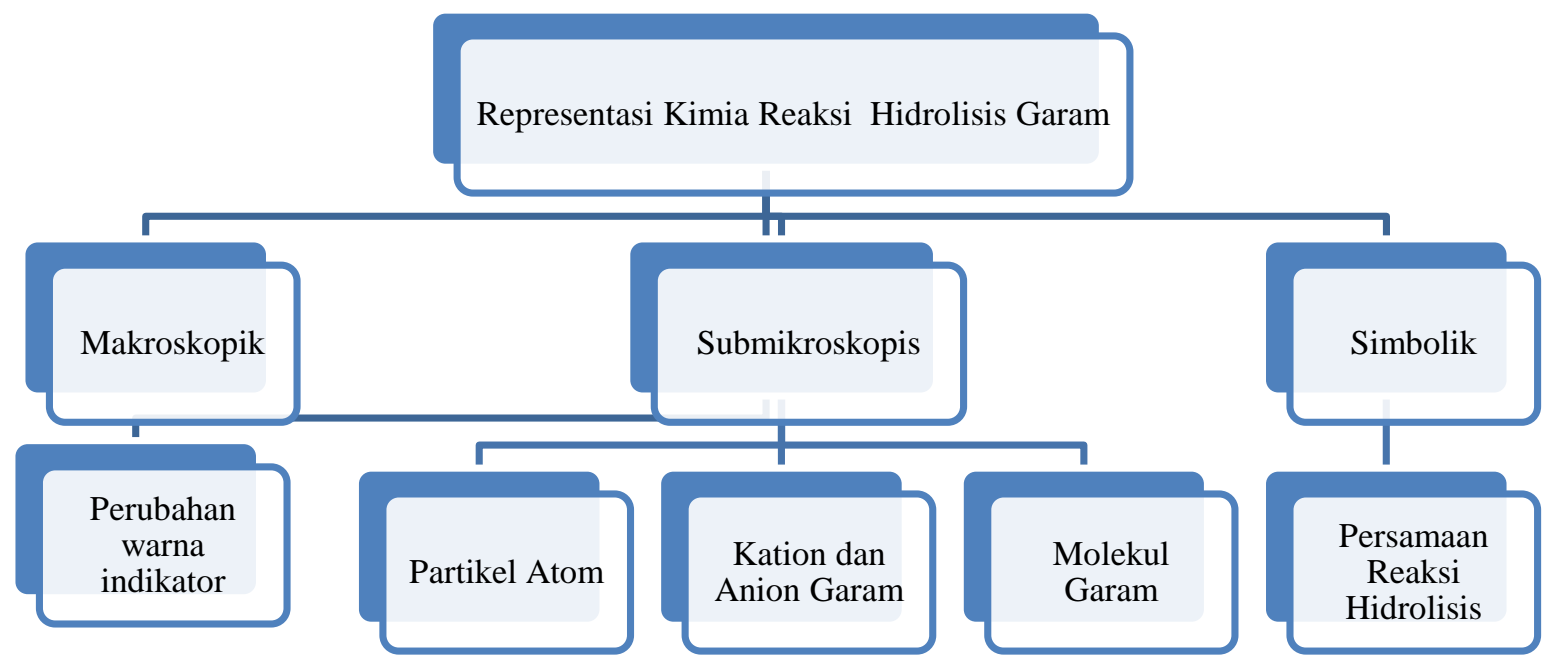

Gambar 2. Representasi Kimia Reaksi Hidrolisis Garam

Istilah yang digunakan untuk merepresentasikan kimia telah mengalami banyak perkembangan (Gilbert dan Treagust, 2010). Pengembangan representasi kimia pada level makroskopis ditunjukkan dengan gambar atau foto, pengamatan fenomena dalam buku teks pelajaran kimia dengan pendekatan mikroskopis dapat meningkatkan kemampuan pemahaman mengenai gejala apa yang terjadi pada tingkat mikroskopis.

Observasi awal buku teks pelajaran kimia menunjukkan perbedaan representasi kimia level makroskopis, mikroskopis dan simbolik dalam desain kegiatan pembelajaran. Pembelajaran bermakna menghubungkan konsep yang dipelajari sebelumnya dengan pemahaman konsep baru. Pendekatan scientific inquiry untuk meningkatkan keterampilan berpikir kritis siswa dan memecahkan masalah dengan konsep yang mudah dipahami dalam buku teks pelajaran kimia. Pengembangan pendekatan scientific inquiry berbasis Problem Based Learning dengan menghubungkan representasi kimia level makroskopis, mikroskopis, dan simbolik dapat dilihat pada tabel 3 .

Tabel 3. Representasi Kimia dalam Buku Teks

\begin{tabular}{llll}
\hline Representasi kimia & \multicolumn{1}{c}{ Buku 1 } & \multicolumn{1}{c}{ Buku 2 } & \multicolumn{1}{c}{ Buku 3 } \\
\hline Makroskopis & $\begin{array}{l}\text { Foto eksperimen, alat dan bahan } \\
\text { laboratorium, fenomena alam, } \\
\text { tumbuh-tumbuhan }\end{array}$ & $\begin{array}{l}\text { Foto eksperimen, alat dan bahan } \\
\text { laboratorium, fenomena alam, } \\
\text { tumbuh-tumbuhan }\end{array}$ & $\begin{array}{l}\text { Foto eksperimen, alat dan bahan } \\
\text { laboratorium, fenomena alam, } \\
\text { tumbuh-tumbuhan }\end{array}$ \\
\hline Mikroskopis & $\begin{array}{l}\text { Gambar rumus struktur, ikatan } \\
\text { kimia, reaksi kimia }\end{array}$ & $\begin{array}{l}\text { Gambar rumus struktur, ikatan kimia, } \\
\text { reaksi kimia, molekul, ion, atom }\end{array}$ & $\begin{array}{l}\text { Gambar rumus struktur, ikatan } \\
\text { kimia, reaksi kimia, molekul, ion, } \\
\text { atom }\end{array}$ \\
\hline Simbolik & $\begin{array}{l}\text { Gambar persamaan reaksi kimia, } \\
\text { persamaan reaksi, grafik, tabel, }\end{array}$ & $\begin{array}{l}\text { Gambar rumus struktur, ikatan kimia, } \\
\text { reaksi kimia,diagram }\end{array}$ & $\begin{array}{l}\text { Gambar rumus struktur, ikatan } \\
\text { kimia, reaksi kimia, diagram }\end{array}$ \\
\hline
\end{tabular}

\section{Tahap Penyebaran (Disseminasi)}

Tahap ini dilakukan terbatas pada pengemasan produk hasil pengembangan, uji keterbacaan dan validasi ahli isi, ahli pembelajaran.

\section{HASIL}

Kajian terhadap buku teks pelajaran kimia untuk menentukan desain pengembangan bahan ajar kimia materi hidrolisis garam ini menggunakan tipe kriteria interpretasi scientific inquiry dalam buku teks pelajaran kimia. Berdasarkan analisis konsep menunjukkan bahwa untuk mempelajari, mengamati dan memecahkan masalah, merumuskan aturan, mencoba untuk menemukan alasan, menentukan ranah aplikasi, meningkatkan penjelasan dibutuhkan kegiatan belajar yang memengaruhi siswa dalam representasi kimia (Tang et al., 2010). Representasi kimia dalam buku teks pelajaran berupa foto, tabel, diagram, persamaan reaksi, peta konsep, grafik, rumus struktur, gambar reaksi kimia, susunan alat-alat laboratorium digunakan untuk menjelaskan hubungan antara ketiga representasi makroskopis, mikroskopis dan simbolik. Penggambaran deskripsi diasumsikan bahwa proses konstruk pengetahuan relevan dengan informasi dan integrasi konsep yang diperlukan siswa untuk merespon pembelajaran (Talanquer, 2011). 
Hasil penelitian menunjukkan bahwa interpretasi terdiri dari interpretasi sesuai dengan karakter sistem klasifikasi (C1), tema berkaitan dengan teks spesifik yang dipelajari (C2), praktik pembelajaran berpusat pada scientific inquiry (C3), teks pelajaran sesuai standar isi (C4), representasi sesuai kompetensi dasar (C5). Sistematika buku teks dengan prinsip dasar integrasi scientific inquiry dalam kegiatan belajar memiliki standar sesuai standard isi, standar proses, standar kurikulum, representasi kimia, scientific inquiry. Data yang diperoleh dari hasil penelitian digunakan sebagai bahan perbandingan dalam pengembangan buku teks pelajaran kimia dengan pendekatan scientific inquiry dapat dilihat pada tabel 4.

Tabel 4. Interpretasi Scientific Inquiry

\begin{tabular}{|l|l|l|l|}
\hline \multirow{2}{*}{ Tipe Kriteria } & \multicolumn{2}{|c|}{ Buku Teks Pelajaran Kimia Kurikulum 2013 untuk SMA/MA } \\
\cline { 2 - 4 } & \multicolumn{1}{|c|}{ Buku 1 } & \multicolumn{1}{c|}{ Buku 2 } & Buku 3 \\
\hline Standar isi & Tema materi pelajaran & Tema berkaitan teks yang dipelajari & Teks pelajaran \\
Standar proses & Teks pelajaran & Teks pelajaran & Tema berkaitan teks yang dipelajari \\
Struktur kurikulum & Tema berkaitan teks yang dipelajari & Interpretasi & Tema berkaitan teks yang dipelajari \\
Representasi kimia & Teks pelajaran & Teks pelajaran & Teks pelajaran \\
Scientific inquiry & Representasi kimia & Representasi kimia & Representasi kimia \\
\hline
\end{tabular}

Berdasarkan data pada tabel 4, diperoleh data bahwa dalam buku teks pelajaran kimia kurikulum 2013 telah mulai dikembangkan dengan pendekatan scientific inquiry mengacu aktivitas siswa dalam mengembangkan sains, ide-ide sains dalam pengertian mengikuti perkembangan pemikiran scientific modern. Grafik interpretasi scientific inquiry dapat dilihat pada gambar 3 .

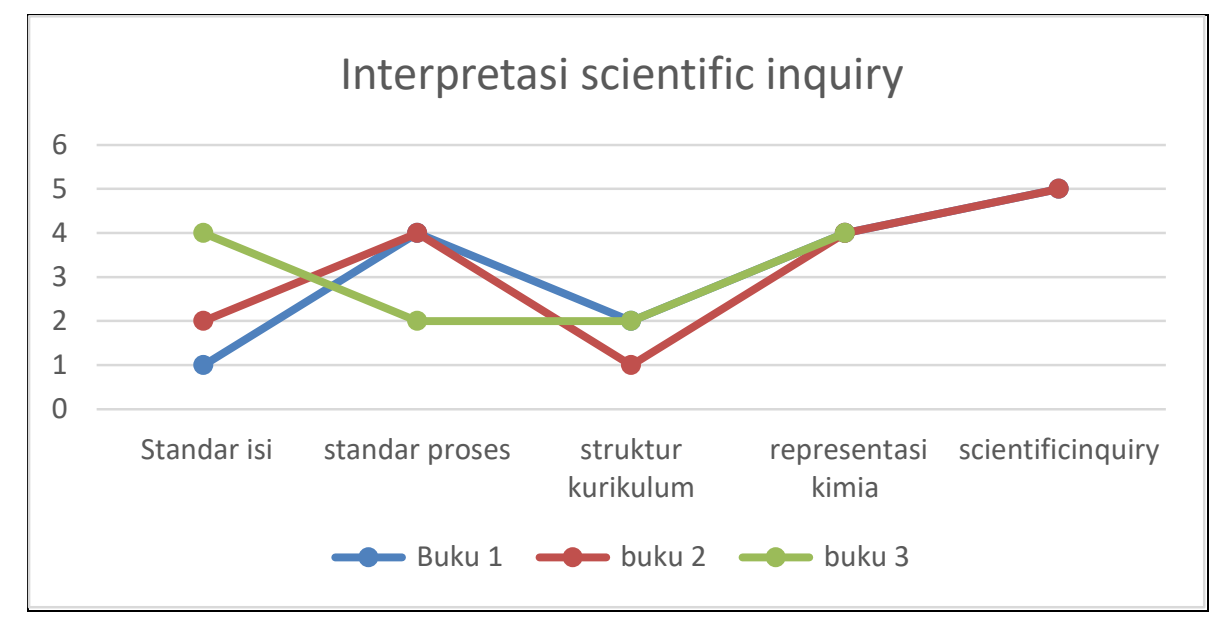

Gambar 3. Grafik Interpretasi Scientific Inquiry Dalam Buku Teks Kurikulum 2013

Grafik menunjukkan bahwa buku teks pelajaran kimia bila dibedakan menggunakan analisis standar isi, standar proses, struktur kurikulum, representasi kimia, scientific inquiry memiliki tipe penyusunan yang berbeda. Buku teks pelajaran kimia sebagai bahan rujukan bahan ajar dengan pendekatan scientific inquiry berbasis problem based learning menunjukkan bahwa scientific inquiry dalam standar penelitian ini menerapkan aspek untuk membentuk pengetahuan, sikap dan keterampilan sesuai kurikulum 2013 (Wijayati, 2017). Buku teks pelajaran kimia dengan representasi kimia terkait dengan scientific inquiry difokuskan dalam pemahaman penyelidikan ilmiah yang membedakan antara hakekat ilmu dengan praktik sains (Barab et al., 2007). Berbagai dokumen menjelaskan pemahaman mendasar karakteristik khusus dari scientific inquiry, meliputi origin (asal) yaitu rasa ingin tahu, pertanyaan ilmiah, contoh peristiwa yang membantu pertanyaan ilmiah, ide-ide ilmiah, gejala, model, teori yang mendukung inquiry, eksperimen contoh pertanyaan yang berbeda mendorong investigasi ilmiah yang berbeda, desain pertanyaan ilmiah (Kazeni et al., 2018).

Scientific inquiry merupakan perlakuan yang penting dalam usaha membangun rasa ingin tahu dan bersikap sosial, tes hipotesis dari berbagai investigasi pertanyaan, problem dan rasa ingin tahu untuk memperoleh pemahaman. Faktor yang terpenting dalam perlakuan scientific inquiry dalam buku teks pelajaran adalah tujuan, eksperimen, tipe data, pengukuran dan karakteristik hasil (Ceylan \& Ozdilek, 2015). Seringkali pengetahuan guru tentang scientific inquiry tidak secara eksplisit dinilai dan diasumsikan bahwa siswa yang melakukan penyelidikan ilmiah akan selalu mengembangkan pemahaman tentang penemuan (Ültay, 2016). Karakteristik scientific inquiry dalam paradigma pembelajaran yang menerapkan pendekatan ilmiah mengacu pada keterampilan proses sains umum dengan konten ilmu pengetahuan alam secara tradisional, mengembangkan kreativitas dan berpikir kritis untuk mengembangkan pengetahuan ilmiah (Lederman et al., 2014b). 
Keterampilan berpikir kritis melalui kegiatan orientasi, observasi, klasifikasi, hipotesis, penyelidikan ilmiah, diskusi, kesimpulan untuk menghasilkan pemahaman konsep hidrolisis garam (Drăghicescu et al., 2014). Kegiatan belajar hasil pengembangan bahan ajar kimia materi hidrolisis garam, meliputi identifikasi sifat asam basa atau netral larutan garam, mengumpulkan data pengamatan perubahan warna indikator kertas lakmus merah dan lakmus biru, menghubungkan data hasil pengamatan dengan terjadinya reaksi hidrolisis garam, hipotesis sifat asam, basa atau netral larutan garam, tes hipotesis sifat asam, basa atau netral larutan garam, reaksi hidrolisis garam. Karakteristik partikel dalam materi, sifat dan komposisi larutan, struktur atom, ikatan ionik dan kovalen, simbol, formula dan persamaan reaksi, ionisasi serta kesetimbangan dalam larutan asam basa dapat menjelaskan kation dan anion garam yang terlarut dalam air (Adlim et al., 2014). Tahap kegiatan belajar dalam bahan ajar divalidasi oleh ahli isi untuk menghasilkan validasi empirik dan hasil belajar yang lebih baik. Berdasarkan hasil validasi diperoleh kegiatan belajar pada tabel 5 .

Tabel 5. Kegiatan Belajar dengan Pendekatan Scientific Inquiry Berbasis Problem Based Learning

\section{Scientific inquiry berbasis Problem Based Learning \\ Siswa merespon jawaban tertulis dari pertanyaan yang digunakan dalam pembelajaran, informasi langsung untuk belajar.}

Belajar menghubungkan teori dengan pengalaman untuk menjelaskan data

Keterampilan menulis untuk berinteraksi dalam group
dan mengelompokkan konsep

Menuliskan hipotesis berdasarkan fakta, issue atau konsep pembelajaran

\section{Kegiatan Belajar}

Orientasi

Dalam literatur dibuka dengan motivasi contoh larutan garam dan pertanyaan penelitian, merumuskan masalah, tujuan pembelajaran

\section{Observasi}

Mencari informasi untuk mengajak siswa latihan inquiry atau investigasi materi belajar

\section{Klasifikasi}

Memfokuskan pertanyaan, eksplorasi reaksi ionisasi larutan garam, reaksi hidrolisis garam

Hipotesis

Menyusun hipotesis sifat asam, basa atau netral larutan garam, menguji hipotesis sifat larutan garam

Penyelidikan Ilmiah Mengumpulkan data $\mathrm{pH}$ air murni, larutan asam, basa atau garam. Melakukan eksperimen atau demonstrasi reaksi dalam larutan garam

Diskusi analisa data, refleksi data hasil pengamatan

Kesimpulan

Membuat kesimpulan untuk menjelaskan hidrolisis garam
Uraian Materi

Mengidentifikasi sifat asam, basa atau netral larutan garam dengan indikator kertas lakmus dan reaksi hidrolisis garam

Mengamati data larutan garam dan reaksi ionisasi larutan garam

Mengelompokkan data hasil pengamatan sifat larutan garam.

Membedakan reaksi hidrolisis garam bersifat asam, basa atau netral

Membuat asumsi sifat asam, basa atau netral larutan garam, hubungan antara sifat asam, basa atau netral larutan garam dengan reaksi hidrolisis garam

Mengidentifikasi data $\mathrm{pH}$ air murni, garam sebagai pupuk ZA (ammonium sulfat), sabun, detergen atau bahan yang lain dalam kehidupan sehari-hari dengan indikator kertas lakmus Menyajikan data hasil pengamatan $\mathrm{pH}$ larutan asam, basa, dan garam. Menganalisis isu lingkungan berkaitan sifat asam, basa atau netral dengan reaksi hidrolisis garam dalam reaksi kimia

Menunjukkan hubungan antara hasil pemahaman dengan variasi konteks berbeda.
Menyimpulkan hubungan konsep hidrolisis garam dengan sifat larutan garam.

Menerapkan konsep pH dan pOH larutan garam yang bersifat asam, basa atau netral

Data kuantitatif hasil pengukuran dan data kualitatif hasil observasi dengan pengukuran yang teratur, reliabilitas, variasi, accuracy/precisi dalam petunjuk atau prosedur menghasilkan kriteria bahan ajar dan kegiatan belajar (Cooper \& Stieff, 2017). Kriteria validasi kegiatan belajar berdasarkan analisis rata-rata dapat dilihat pada tabel 6 .

Tabel 6. Kriteria Validasi Analisis Rata-rata

\begin{tabular}{ll}
\hline Skor & Kriteria Validasi \\
\hline $3,26-4,00$ & Valid, tidak perlu revisi \\
$2,51-3,25$ & Cukup Valid, tidak perlu revisi \\
$1,76-2,50$ & Kurang valid, perlu revisi \\
$1,00-1,75$ & Tidak valid, revisi total \\
\hline
\end{tabular}


Karakteristik hasil scientific inquiry bersifat empirik, tentatif, tesable, tidak dapat dipalsukan, refleksi diri untuk membangun intelegensi, kejujuran, tekun, toleransi untuk makna ganda, membuka pengetahuan baru dan membangun pengetahuan publik dengan pemikiran scientific modern (Stone, 2014). Konsep data kuantitatif disertai dengan data kualitatif dan konsep kelas, misalnya asam, basa, garam, elemen yang digunakan untuk mengklasifikasi zat dan membantu refleksi praktik sains modern lebih akurat dalam kegiatan laboratorium, mendapatkan jawaban pertanyaan, memulai proses pengumpulan data dengan eksperimen, observasi, survey dan investigasi ilmiah.

Scientific inquiry dalam penelitian ini tidak secara eksplisit dinilai dan diasumsikan bahwa siswa yang melakukan penyelidikan ilmiah akan selalu mengembangkan pemahaman tentang penemuan (Susianna, 2011). Pendekatan scientific inquiry dalam paradigma pembelajaran menerapkan pendekatan ilmiah mengacu pada keterampilan proses sains dengan konten ilmu pengetahuan, membangun kreativitas dan berpikir kritis untuk mengembangkan pengetahuan ilmiah (Lederman et al., 2014a). Penyelidikan ilmiah untuk mengembangkan kemampuan siswa menginferensi hasil pengamatan derajat keasaman (pH), menyusun data yang valid dan membuat kesimpulan (Rahayu et al., 2011) ditunjukkan pada tabel 7.

Tabel 7. Karakteristik Scientific Inquiry

\begin{tabular}{llll}
\hline \multirow{2}{*}{ Tipe Kriteria } & \multicolumn{2}{c}{ Buku Teks Pelajaran Kimia } & Kurikulum 2013 untuk SMAMA \\
\cline { 2 - 4 } & Tujuan & Eksperimen & Hasil \\
\hline Observasi & Aktivitas & Penelitian & Empiris \\
Mengumpulkan informasi & Pembenaran & Tes Hipotesis & Tentatif \\
Identifikasi variabel & Accuracy/Presisi & Investigasi Ilmiah & Tesable \\
Formula & Ide-Ide Ilmiah & Investigasi Ilmiah & Empiris \\
Test Hipotesis & Teori yang Mendukung Inkuiri & Desain Pertanyaan Ilmiah & Tentatif \\
& & & \\
Prediksi & Data Hasil & Prosedur & Empiris \\
Akurasi & Prosedur & Refleksi Diri & Tentatif \\
Reliabel & Data Kuantitatif & Refleksi Diri & Variasi \\
\hline
\end{tabular}

Hasil validasi empiris tahap define, design, dan develop dihasilkan produk pengembangan dalam bentuk bahan ajar yang mencakup skema materi kegiatan belajar, petunjuk penggunaan bahan ajar, garis besar isi buku, kegiatan belajar, silabus dan rencana pelaksanaan pembelajaran dengan tahapan kegiatan validasi sebagai berikut.

Pertama, validasi sebagai data empiris keterbacaan buku siswa melalui konsultasi dengan dosen pembimbing dan revisi. Data revisi untuk mendapatkan data kelayakan, penilaian dan saran perbaikan desain awal produk pengembangan. Data kelayakan diperoleh melalui implementasi bagian kegiatan belajar, kajian penelitian terdahulu dan konsultasi dengan dosen pembimbing. Kedua, hasil saran dan konsultasi digunakan untuk menyusun revisi skema kegiatan belajar dalam bentuk peta konsep. Ketiga, peta konsep merupakan penjelasan dari setiap kegiatan belajar yang harus diketahui oleh siswa sebagai pedoman untuk mengumpulkan informasi dan sumber belajar yang dibutuhkan sebagai rancangan sintaks kegiatan belajar. Keempat, sintaks kegiatan belajar dalam penelitian ini merupakan integrasi dari pendekatan scientific inquiry berbasis problem based learning merupakan salah satu pengembangan kegiatan belajar untuk mengembangkan working memory siswa.

Pembahasan tentang materi kegiatan belajar melalui validasi ahli isi, materi pembelajaran untuk mendapatkan saran dan perbaikan bahan ajar kimia menunjukkan bahwa pengembangan bahan ajar kimia yang valid dapat ditingkatkan melalui pengorganisasian materi belajar, meliputi struktur, konten, metode evaluasi, dan pendekatan yang sesuai. Hasil analisis validasi bahan ajar dapat dilihat pada data hasil validasi kelayakan tabel 8.

Tabel 8. Hasil Analisis Validasi Kelayakan Bahan Ajar

\begin{tabular}{clcl}
\hline No. & Dimensi & Nilai Rata-rata & Kriteria Validasi \\
\hline 1. & Struktur Bahan Ajar & 3,56 & Valid, tidak perlu revisi \\
2. & Komponen Bahan Ajar & 3,60 & Valid, tidak perlu revisi \\
3. & Kreativitas Siswa dalam Bahan Ajar & 3,67 & Valid, tidak perlu revisi \\
4 & Scientific inquiry berbasis Problem Based Learning & 3,67 & Valid, tidak perlu revisi \\
\hline & Rata-rata & 3,60 & Valid, tidak perlu revisi \\
\hline
\end{tabular}

Kegiatan belajar diasumsikan bahwa proses konstruk pengetahuan relevan dengan informasi dan integrasi konsep yang diperlukan siswa untuk merespon pembelajaran (Buxner, 2015). Proses pembelajaran sesuai dengan kondisi siswa terkait erat dengan pendekatan scientific inquiry yang dipilih untuk membantu siswa meningkatkan pemahaman konsep dan mengembangkan keterampilan berpikir kritis. Produk hasil pengembangan bahan ajar dalam penelitian ini dalam upaya pemahaman konsep dengan pendekatan scientific inquiry berbasis Problem Based Learning hasil validasi empirik menunjukkan kelayakan dan keefektifan sebagai bahan ajar. Berdasarkan pembahasan data hasil kajian validasi proses pembelajaran yang mengonfirmasi hasil belajar diperoleh kesimpulan bahwa bahan ajar yang digunakan dan berlaku di dalam kelas tidak dapat diuji hanya dengan kajian pustaka 
atau dalam keadaan pembelajaran biasa sesuai kurikulum saja. Hal ini menunjukkan bahwa perlu hati-hati dalam merancang kegiatan belajar sehingga komponen dan kondisi yang cukup mendekati proporsi dapat dicapai siswa dalam pembelajaran menghasilkan proses belajar efektif. Kriteria keefektifan dan kelayakan bahan ajar pada tabel 8 jika dikualifikasikan dalam skala penilaian (\%) dapat dilihat pada tabel 9.

Tabel 9. Kualifikasi Penilaian Tingkat Kelayakan Produk Pengembangan

\begin{tabular}{lll}
\hline Skala Penilaian (\%) & Kriteria & Kategori \\
\hline $85-100$ & Sangat baik/sangat menarik/sangat sesuai/sangat efektif & Tidak perlu revisi \\
$65-84$ & Baik/menarik/sesuai/efektif & Direvisi sedikit \\
$45-64$ & Kurang baik/kurang menarik/kurang sesuai/kurang efektif & Direvisi \\
$0-44$ & Sangat kurang & Direvisi \\
\hline
\end{tabular}

Tabel kualifikasi kelayakan di atas untuk menentukan persentase (\%) keefektifan produk hasil pengembangan pada saat digunakan dalam proses pembelajaran di kelas. Hasil analisis keefektifan bahan ajar menunjukkan bahwa bahan ajar memiliki kriteria kelayakan sangat baik, tidak perlu revisi dan efektif sebagai bahan ajar. Data hasil analisis dapat dijelaskan dari aspek pembelajaran yang memungkinkan tumbuhnya kebiasaan positif bagi siswa dalam kegiatan belajar produk hasil pengembangan dapat dilihat pada tabel 10 .

Tabel 10. Hasil Analisis Keefektifan Produk Pengembangan

\begin{tabular}{|c|c|c|c|}
\hline No. & Aspek Penilaian & Skala Penilaian (\%) & Kriteri Kelayakan \\
\hline 1. & $\begin{array}{l}\text { Pembelajaran sesuai dengan tujuan (kompetensi yang akan dicapai, } \\
\text { indikator pencapaian kompetensi dan tujuan pembelajaran) }\end{array}$ & 92 & Sangat baik tidak perlu revisi \\
\hline 2. & $\begin{array}{l}\text { Kesesuaian dengan pembukaan, kegiatan inti: kesesuaian sintaks } \\
\text { dengan strategi dan kegiatan penutup }\end{array}$ & 92 & Sangat baik tidak perlu revisi \\
\hline 3. & $\begin{array}{l}\text { Keruntutan dan kejelasan deskripsi pembelajaran sesuai dengan } \\
\text { hierarki belajar }\end{array}$ & 92 & Sangat baik tidak perlu revisi \\
\hline 4. & Pembelajaran yang memungkinkan tumbuhnya kebiasaan positif & 92 & Sangat baik, tidak perlu revisi \\
\hline \multirow[t]{2}{*}{5.} & Pemanfaatan alokasi waktu yang proporsional untuk kegiatan belajar & 75 & Baik direvisi sedikit \\
\hline & Rata-rata & 89 & Sangat baik, tidak perlu revisi \\
\hline
\end{tabular}

\section{SIMPULAN}

Penerapan scientific inquiry terkait erat dengan proses ilmiah dalam keterampilan proses kegiatan belajar menggunakan produk hasil pengembangan dalam penelitian ini adalah kegiatan belajar dengan melibatkan siswa untuk menghasilkan produk berupa bahan ajar kimia materi hidrolisis garam. Berdasarkan data hasil validasi menunjukkan bahwa dengan pendekatan Scientific inquiry berbasis Problem Based Learning dapat disimpulkan sebagai berikut. Pertama, hasil validasi kegiatan belajar oleh ahli isi, ahli materi dan ahli pembelajaran menunjukkan nilai rata-rata 3,67 dengan kriteria valid dan tidak perlu revisi. Kedua, data kuantitatif kompetensi dasar yang dipelajari dan representasi kimia menunjukkan bahwa kegiatan belajar dalam buku teks hasil pengembangan berdasarkan hasil validasi kelayakan bahan ajar memiliki kelayakan rata-rata 3,60. Kriteria dapat dijelaskan bahwa struktur bahan ajar, komponen bahan ajar, kreativitas siswa dalam bahan ajar, scientific inquiry berbasis problem based learning yang diterapkan valid, tidak perlu revisi. Ketiga, materi hidrolisis garam dalam bahan ajar menunjukkan bahwa tahap kegiatan belajar dalam bahan ajar divalidasi oleh ahli isi untuk menghasilkan validasi empirik dengan skor rata-rata 3,67 yang valid dan tidak perlu revisi. Keempat, hasil belajar yang lebih baik dan proses pembelajaran dengan menggunakan bahan ajar hasil pengembangan lebih efektif berdasarkan data hasil validasi empirik dengan rata-rata skala penilaian $89 \%$.

Saran bagi guru kimia dan peneliti lain dalam upaya mengembangkan bahan ajar kimia materi hidrolisis garam secara terintegrasi dalam ide sains dan belajar bermakna peneliti memberikan saran sebagai berikut. Pertama, Keterampilan berpikir kritis menerapkan higher order thinking skills Taksonomi Blooms aplikasi, analisa, sintesa, kreatif untuk mengembangkan aktivitas belajar siswa perlu dikembangkan dengan pendekatan scientific inquiry berbasis problem based learning. Kedua, Literasi kimia, pemahaman algoritmik, pengetahuan kognitif, keterampilan proses sains yang berpengaruh signifikan bagi siswa untuk pemahaman konsep dan mengembangkan keterampilan berpikir kritis dapat diterapkan dalam proses belajar. Ketiga, Pengembangan lebih lanjut diperlukan untuk memperoleh bentuk buku teks pelajaran kimia yang valid dari segi isi dan konstruk berkaitan dengan kelayakan buku sebagai bahan ajar dalam ruang lingkup lebih luas skala kelompok. Keempat, Validasi buku berkaitan dengan kelayakan buku sebagai bahan ajar skala kelompok yang lebih luas. 


\section{DAFTAR RUJUKAN}

Adlim, M., S, S., Ali, H., Ibrahim, A., Umar, H., Ismail, K., Gani, U. A., Hasan, I., \& Yasin, B. (2014). Assessing ChemistryLearning Competencies of Students in Isolated Rural Senior High Schools By Using the National Examination: A Case Study of Simeulue Island, Indonesia. International Journal of Science and Mathematics Education, 12(4), 817-839. https://doi.org/10.1007/s10763-013-9440-x

Barab, S. A., Sadler, T. D., Heiselt, C., Hickey, D., \& Zuiker, S. (2007). Relating Narrative, Inquiry, and Inscriptions: Supporting Consequential Play. Journal of Science Education and Technology, 16(1), 59-82. https://doi.org/10.1007/s10956-006-9033-3

Borda, E., Boudreaux, A., Fackler-Adams, B., Frazey, P., Julin, S., Pennington, G., \& Ogle, J. (2017). Adapting a StudentCentered Chemistry Curriculum to a Large-Enrollment Context: Successes and Challenges. Journal of College Science Teaching, 046(05), 8-14. https://doi.org/10.2505/4/jcst17_046_05_8

Burgess, A., Roberts, C., Ayton, T., \& Mellis, C. (2018). Implementation of Modified Team-Based Learning within a Problem Based Learning Medical Curriculum: A Focus Group Study. BMC Medical Education, 18(1), 1-7. https://doi.org/10.1186/s12909-018-1172-8

Buxner, S. R. (2015). Exploring How Research Experiences For Teachers Changes Their Understandings of The Nature of Science And Scientific Inquiry. Journal of Astronomy \& Earth Sciences Education (JAESE), 1(1), 53. https://doi.org/10.19030/jaese.v1i1.9107

Çalik, M., Özsevgeç, T., Ebenezer, J., Artun, H., \& Küçük, Z. (2014). Effects of “Environmental Chemistry” Elective Course Via Technology-Embedded Scientific Inquiry Model on Some Variables. Journal of Science Education and Technology, 23(3), 412-430. https://doi.org/10.1007/s10956-013-9473-5

Ceylan, S., \& Ozdilek, Z. (2015). Improving a Sample Lesson Plan for Secondary Science Courses within the STEM Education. Procedia - Social and Behavioral Sciences, 177(July 2014), 223-228. https://doi.org/10.1016/j.sbspro.2015.02.395

Cooper, M. M., \& Stieff, M. (2017). Sketching the Invisible to Predict the Visible : From Drawing to Modeling in Chemistry. 9 , 902-920. https://doi.org/10.1111/tops.12285

Drăghicescu, L. M., Petrescu, A. M., Cristea, G. C., Gorghiu, L. M., \& Gorghiu, G. (2014). Application of Problem-based Learning Strategy in Science Lessons - Examples of Good Practice. Procedia - Social and Behavioral Sciences, 149, 297-301. https://doi.org/10.1016/j.sbspro.2014.08.245

Gültepe, N. (2016). Reflections on High School Students' Graphing Skills and their Conceptual Understanding of Drawing Chemistry Graphs. Kuram ve Uygulamada Egitim Bilimleri, 16(1), 53-81. https://doi.org/10.12738/estp.2016.1.2837

IGCSE Cambridge. (2015). Syllabus Cambridge Secondary 2 Version 1. August. http://www.cie.org.uk/images/167037-20162018-syllabus.pdf

Johnson, R. E., Rosen, C. C., \& Chang, C. H. (2011). To Aggregate or Not to Aggregate: Steps for Developing and Validating Higher-Order Multidimensional Constructs. Journal of Business and Psychology, 26(3), 241-248. https://doi.org/10.1007/s10869-011-9238-1

Kazeni, M., Baloyi, E., \& Gaigher, E. (2018). Effectiveness of Individual and Group Investigations in Developing Integrated Science Inquiry Skills. South African Journal of Education, 38(3), 1-12. https://doi.org/10.15700/saje.v38n3a1549

Knaus, K., Murphy, K., Blecking, A., \& Holme, T. (2011). A Valid and Reliable Instrument for Cognitive Complexity Rating Assignment of Chemistry Exam Items. Journal of Chemical Education, 88(5), 554-560. https://doi.org/10.1021/ed900070y

Koçakoğlu, M., Bakar, E., \& Keleş, Ö. (2010). The Comparision of the Science and Technology Curriculum with the Physics, Chemistry and Biology Curriculums. Procedia - Social and Behavioral Sciences, 2(2), 282-289. https://doi.org/10.1016/j.sbspro.2010.03.011

Lederman, J. S., Lederman, N. G., Bartos, S. A., Bartels, S. L., Meyer, A. A., \& Schwartz, R. S. (2014a). Meaningful Assessment of Learners' Understandings about Scientific Inquiry - The Views about Scientific Inquiry (VASI) Questionnaire. Journal of Research in Science Teaching, 51(1), 65-83. https://doi.org/10.1002/tea.21125

Lederman, J. S., Lederman, N. G., Bartos, S. A., Bartels, S. L., Meyer, A. A., \& Schwartz, R. S. (2014b). Meaningful Assessment of Learners 'Understandings about Scientific Inquiry - The Views About Scientific Inquiry (VASI) Questionnaire. 51(1), 65-83. https://doi.org/10.1002/tea.21125

Naah, B. M., \& Sanger, M. J. (2013). Investigating Students' Understanding of the Dissolving Process. Journal of Science Education and Technology, 22(2), 103-112. https://doi.org/10.1007/s10956-012-9379-7

Osman, K., Hiong, L. C., \& Vebrianto, R. (2013). $21^{\text {st }}$ Century Biology: An Interdisciplinary Approach of Biology, Technology, Engineering and Mathematics Education. Procedia - Social and Behavioral Sciences, 102(Ifee 2012), 188194. https://doi.org/10.1016/j.sbspro.2013.10.732

Rahayu, S., Chandrasegaran, A. L., Treagust, D. F., Kita, M., \& Ibnu, S. (2011). Understanding Acid-Base Concepts: Evaluating the Efficacy of a Senior High School Student-Centred Instructional Program in Indonesia. International Journal of Science and Mathematics Education, 9(6), 1439-1458. https://doi.org/10.1007/s10763-010-9272-x 
Rahayu, S., \& Kita, M. (2010). An Analysis of Indonesian and Japanese Students' Understandings of Macroscopic and Submicroscopic Levels of Representing Matter and its Changes. International Journal of Science and Mathematics Education, 8(4), 667-688. https://doi.org/10.1007/s10763-009-9180-0

Saukkoriipi, J., \& Laasonen, K. (2010). Theoretical Study of the Hydrolysis of Pentameric Aluminum Complexes. In Journal of Chemical Theory and Computation (Vol. 6, Issue 4). https://doi.org/10.1021/ct900670a

Schwarz, C. V., Reiser, B. J., Davis, E. A., Kenyon, L., Achér, A., Fortus, D., Shwartz, Y., Hug, B., \& Krajcik, J. (2009). Developing a Learning Progression for Scientific Modeling: Making Scientific Modeling Accessible and Meaningful for Learners. Journal of Research in Science Teaching, 46(6), 632-654. https://doi.org/10.1002/tea.20311

Şener, N., \& Tü, C. (2015). Improving Science Attitude and Creative Thinking through Science Education Project : A Design , Implementation, and Assessment. 3(4), 57-67. https://doi.org/10.11114/jets.v3i4.771

Shwartz, Y., Ben-Zvi, R., \& Hofstein, A. (2006). The Use of Scientific Literacy Taxonomy for Assessing the Development of Chemical Literacy among High-School Students. Chemistry Education Research and Practice, 7(4), $203-225$. https://doi.org/10.1039/B6RP90011A

Stone, E. M. (2014). Guiding Students to Develop an Understanding of Scientific Inquiry: A Science Skills Approach to Instruction and Assessment. CBE Life Sciences Education, 13(1), 90-101. https://doi.org/10.1187/cbe-12-11-0198

Susianna, N. (2011). The Chemistry Teaching Program for Developing the Senior High School Students' Entrepreneurial Attitudes. Online Submission, 7, 909-923.

Tang, X., Coffey, J. E., Elby, A., \& Levin, D. M. (2010). The Scientific Method and Scientific Inquiry: Tensions in Teaching and Learning. Science Education, 94(1), 29-47. https://doi.org/10.1002/sce.20366.

Ültay, N. (2016). A Comparison of Different Teaching Designs of 'Acids and Bases 'Subject. 12(1), 57-86. https://doi.org/10.12973/eurasia.2016.1422a

Wang, L., Zhang, R., Clarke, D., \& Wang, W. (2014). Enactment of Scientific Inquiry: Observation of Two Cases at Different Grade Levels in China Mainland. Journal of Science Education and Technology, 23(2), 280-297. https://doi.org/10.1007/s10956-013-9486-0

Wijayati, N. (2017). International Journal of Active Learning Application of Project Based Learning (PBL) Model for Materials of Salt Hydrolysis to Encourage Students 'Entrepreneurship Behaviour, 2(1), 50-58. 